\title{
Indirect evidence for body size reduction in a flightless island bird after human colonisation
}

\author{
Jörn Theuerkauf ${ }^{1}\left[\right.$ [D $\cdot$ Roman Gula ${ }^{1}$ (])
}

Received: 11 January 2018 / Revised: 16 February 2018 / Accepted: 19 February 2018 / Published online: 27 February 2018

(c) The Author(s) 2018. This article is an open access publication

\begin{abstract}
Rhynochetos orarius has been described from Holocene fossils as the sister species of the smaller extant Kagu Rhynochetos jubatus, a bird endemic to New Caledonia. However, we argue that there has never been evidence justifying the description of $R$. orarius. Additionally, for biogeographical reasons it seems unlikely that two Kagu species would have evolved in New Caledonia. We therefore synonymise $R$. orarius and $R$. jubatus and postulate that Holocene Kagu were larger than today probably because historic hunting by humans targeted larger birds in richer habitat.
\end{abstract}

Keywords Biological invasion $\cdot$ Human impact $\cdot$ Kagu $\cdot$ New Caledonia $\cdot$ Pacific $\cdot$ Rhynochetos jubatus

\section{Zusammenfassung}

Indirekter Nachweis für Verkleinerung der Körpergröße einer flugunfähigen Vogelart nach Besiedlung ihrer Insel durch Menschen

Basierend auf Fossilien aus dem Holozän ist Rhynochetos orarius als Schwesterart des rezenten Kagus Rhynochetos jubatus, einer endemischen Vogelart Neukaledoniens, beschrieben worden. Wir finden jedoch, dass es nie Befunde gab, die die Beschreibung von $R$. orarius rechtfertigten. Darüber hinaus scheint es aus biogeografischen Gründen unwahrscheinlich, dass sich zwei Kaguarten in Neukaledonien gebildet hätten. Wir synonymisieren daher $R$. orarius und $R$. jubatus und gehen davon aus, dass Holozäne Kagus größer waren als heute, wahrscheinlich weil Menschen in historischer Zeit gezielt größere Vögel in fruchtbareren Lebensräumen gejagt haben.

\section{Introduction}

Humans colonising the Pacific islands had a strong impact on large-bodied flightless birds through hunting, and many of these species became subsequently extinct (Steadman and Martin 2003). This was also the case in New Caledonia, where only one flightless bird species, the Kagu Rhynochetos jubatus, survived, whereas about 20 species became extinct (Anderson et al. 2010). However, if large body size was an important reason for human-caused extinction of

Communicated by F. Bairlein.

Jörn Theuerkauf

jtheuer@miiz.eu

Roman Gula

rgula@miiz.eu

1 Museum and Institute of Zoology, Polish Academy of Sciences, Wilcza 64, 00-679 Warsaw, Poland some species, there might also have been a selection pressure towards smaller body size in species that survived the arrival of humans.

Balouet and Olson (1989) found fossil Kagu bones from the Holocene (about 1800 years ago) that were larger than those of extant Kagu. They described the fossil Kagu as a new species, Rhynochetos orarius, from deposits in the Pindai Cave (west coast of Grande Terre, the mainland of New Caledonia; Fig. 1). Balouet and Olson (1989) furthermore assumed that " $R$. orarius and $R$. jubatus were lowland and highland forms, respectively" (p. 32, last paragraph in the left row). In this paper, we review Balouet and Olson (1989) and argue that $R$. orarius should never have been described as a new species. We also argue that it seems unlikely that two species would have evolved in New Caledonia. Therefore, the fossil remains of Kagu potentially provide evidence that the body size of Kagu substantially decreased during the last two millennia with human presence. 
Fig. 1 Locations of caves at Pindai (Grande Terre) and Kanumera (Île des Pins) with Holocene Kagu bones (black triangles) in New Caledonia (area above $400 \mathrm{~m}$ in dark grey) and relative size of 33 bone measurements of Holocene Kagu compared to extant Kagu (data from Balouet and Olson 1989) on Grande Terre (white box-and-whisker plot) and Île des Pins (grey box-and-whisker plot)

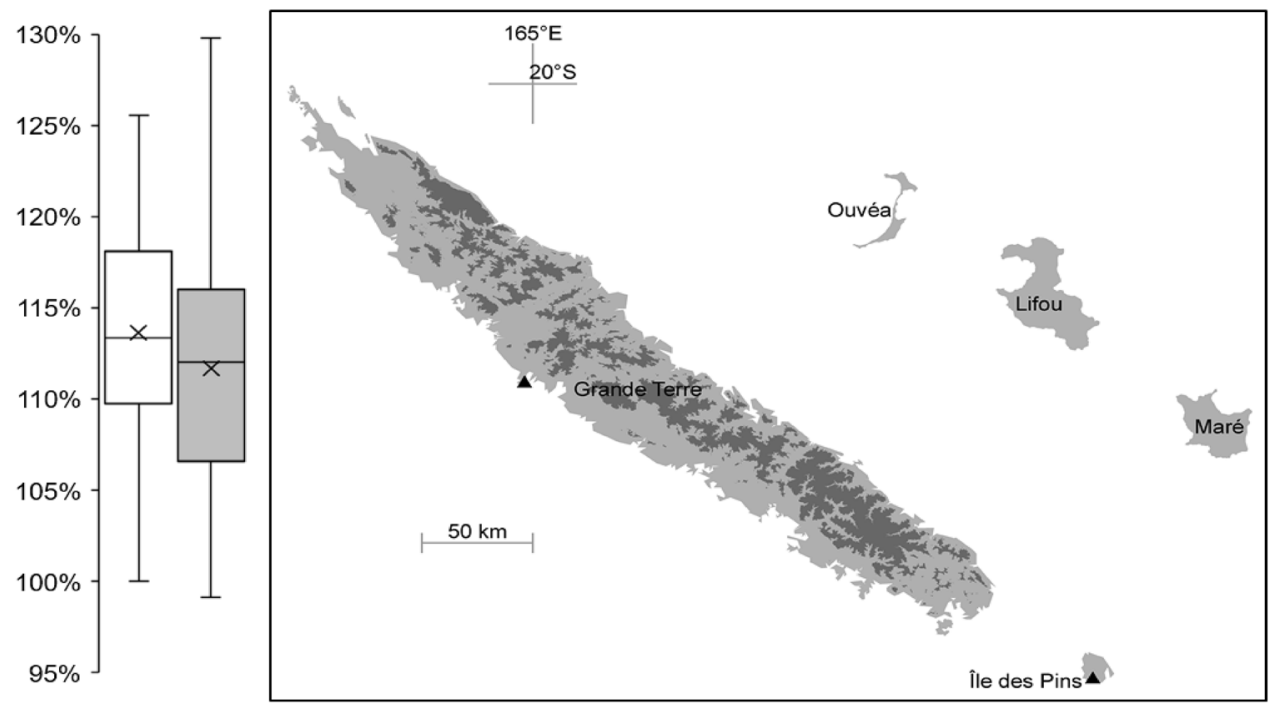

\section{No evidence for a second Kagu species}

Balouet and Olson (1989) described $R$. orarius based on the assumption "unless we postulate that all Kagu have become much smaller within only a few centuries, which seems highly unlikely, then the fossils must represent a form that is taxonomically distinct from $R$. jubatus" (p. 32,5 th paragraph). They further acknowledged that "the general proportions of the different bones are very similar in the two species" and that the only differences in anatomy were that "in $R$. orarius the tibiotarsi have the inner condyle deeper than the width of the distal end (Fig. 16a) [in Balouet and Olson 1989] and the tarsometatarsi have a deeper anterior groove that extends nearly to the distal foramen, whereas this groove is less pronounced and restricted to the proximal half of the bone in R. jubatus" (Balouet and Olson 1989, p. 32, 2nd paragraph). Anderson et al. (2010) also studied fossil Kagu in New Caledonia and doubted that the size difference in bones was enough to ensure the validity of $R$. orarius. They wrote that "Balouet \& Olson (1989) described an extinct Kagu from bones at Pindai as Rhynochetos orarius on the basis that it was slightly bigger than $R$. jubatus. The difference is minor and of a scale often seen in populations of larger gruiforms [...] so $R$. orarius may be a slight geographical variant not worthy of specific status" (Anderson et al. 2010, p. 101,2 nd paragraph). The currently accepted phylogenetic position of the Kagu is as a sister taxon of the Sunbittern Eurypyga helias (Hackett et al. 2008) within the Aequorlitornithes clade, near the Gruiformes clade (Prum et al. 2015). Furthermore, Balouet and Olson (1989) found only the alleged larger Kagu species in the examined deposits located in the lowlands but never found any bones that they could assign to $R$. jubatus, which means that there is no evidence that two species of Kagu co-existed in the Holocene. We think that basing a species description just on an assumption, without any proof of the existence of two species and little evidence for autapomorphies, does not warrant the description of a species. We therefore consider $R$. orarius as an invalid species and a synonym of $R$. jubatus. As the latter was first described, the correct name for all Kagu would be Rhynochetos jubatus Verreaux \& Des Murs, 1860.

\section{Biogeographical and ecological reasons to doubt the existence of two Kagu species}

Besides lack of taxonomic evidence for two Kagu species, there are also biogeographical reasons to doubt their existence. New Caledonia was submerged until about 37 million years ago (Grandcolas et al. 2008), meaning that a flying ancestor of the Kagu must have colonised the island after this submersion and subsequently lost its flight ability. Kagu diverged from their nearest relative, the Neotropical Sunbittern, which still has flight ability, probably in the Oligocene, about 35 million years ago (Fain and Houde 2004), so it is likely that Kagu colonised New Caledonia from Gondwana just after its re-emersion. On the archipelago, there was little potential for separation of the alleged mountain and lowland species. The best chances for allopatric speciation would have been on Grande Terre and Île des Pins, which were connected in glacial periods (as the lagoon between the islands is shallow) and separated in warmer periods (as today). However, Balouet and Olson (1989) found bones of the same larger Kagu form on both islands, which excludes this possibility for allopatric speciation. The only circumstances for allopatric speciation on Grande Terre would have 
been through elevational separation since the highest mountains on Grande Terre reach $1600 \mathrm{~m}$ a. s. 1. However, extant Kagu live from the lowlands (Theuerkauf et al. 2015) to high-elevational sites (Hunt et al. 1996). Even if there had been a lowland and a highland form of Kagu, there would not have been any barrier preventing genetic flow throughout elevations, because the western lowland region and the central mountain range are adjacent (Fig. 1) and inter-connected, preventing the establishment of two species. The same is true if we consider habitat as a potential separation factor since the major part of New Caledonia was covered by forest that gradually changed from dry forest in the west to rainforest in the east (Jaffré et al. 1998). Considering that the dispersal distances of individual Kagu are at least up to $12 \mathrm{~km}$ (Létocart 2000), there was likely genetic exchange throughout the forest and no possibility for speciation. Sympatric speciation in birds is rare (Phillimore et al. 2008) and given that Kagu have a generalist carnivorous diet (Hunt 1996a), we do not see much potential for niche separation.

\section{Body size and body mass reduction in Kagu}

Given that $R$. orarius should never have been described as a new species, the Holocene Kagu bones likely belong to $R$. jubatus. Therefore, Balouet and Olson (1989) provide indirect evidence that Kagu had larger bones 1800 years ago than today. Based on the measurements in Balouet and Olson (1989), we estimated body mass for Holocene and extant Kagu with the equations provided in Field et al. (2013), taking into consideration the length of tarsus (7\% longer in Holocene compared to extant Kagu), humerus (10\%), femur (10\%), tibia (13\%), and coracoid (15\%). Estimations for body mass of Holocene Kagu were $16 \%$ (based on tarsus) to $41 \%$ (based on coracoid) larger than that of extant Kagu. Given that the average size difference of bones between Holocene and extant Kagu is about 14\% (Fig. 1), the average body mass of Holocene Kagu would rather have been around $40 \%$ larger than that of extant Kagu.

\section{Possible reasons for body size reduction}

Body size of prey can rapidly change in response to the introduction of a new predator (Fisk et al. 2007). For example, body size of European Mink (Mustela lutreola) decreased within 10 years after introduction of a competitor (Sidorovich et al. 1999). In Australia, body size of snakes increased less than 70 years after the introduction of an invasive toad (Phillips and Shine 2004). Relatively rapid changes in body size have also been found in birds, as body size of birds introduced to New Zealand changed up to $4 \%$ within 150 years (Blackburn et al. 2013). We think that, as the fossil bones of Kagu were leftovers in inhabited caves (Balouet and Olson 1989), the most likely reason for the body size reduction of Kagu was predation by humans. Hunters probably selected larger Kagu and areas of high density for hunting Kagu, which were probably the areas of best Kagu habitat. However, one-third of New Caledonia consists of ultramafic regions, which are generally uninhabitable for humans due to the poor ultramafic soils rich in heavy metals (Latham et al. 1978). As Kagu have the ability to withstand high heavy metal contents (Theuerkauf et al. 2015), these ultramafic areas likely served as a refuge habitat for Kagu (Theuerkauf et al. 2017). The introduction of dogs in 1774 (Gargominy et al. 1996), which are nowadays the main predator of Kagu (Hunt et al. 1996), probably reinforced Kagu being pushed into suboptimal habitats far from human settlements (Hunt 1996b), as dogs do not establish sustainable populations in the wild (Rouys and Theuerkauf 2003). At the end of the nineteenth century, Layard and Layard (1882) noted that the Kagu "has now nearly disappeared from the neighbourhood of the more settled and inhabited parts. It is usually caught by natives with dogs among rocks and stones in precipitous ravines in the mountains" (p. 534, last paragraph).

Ultramafic areas, however, are suboptimal habitat and extant Kagu are $10 \%$ lighter on ultramafic soil than in other areas (Theuerkauf et al. 2017). Applying the conversion equations by Field et al. (2013), the $10 \%$ lower body mass would correspond to Kagu being about $4 \%$ smaller in ultramafic areas. The samples of Kagu of Balouet and Olson (1989) were about $1.5 \%$ smaller on Île des Pins (which has large areas of ultramafic soils) than on Grande Terre in the Holocene (Fig. 1), indicating that also in the Holocene, there were probably differences in body size dependent on habitat richness. In addition to selective hunting, the suboptimal habitat might therefore have contributed to the body size reduction. If smaller individuals were better adapted to the poor environmental conditions in the refuge habitat, then there might have been selection towards smaller body size. However, the $10 \%$ body mass difference nowadays is only caused by environmental differences, as Kagu recently recolonised the study site on non-ultramafic soil (Theuerkauf et al. 2017) from the refuge habitat.

Our findings have implications for both island biogeography and invasion biology. Knowledge of body size is crucial for island biogeography (Santos et al. 2016). Although studies testing for example Bergmann's rule (Olson et al. 2009) or the island rule (Boyer and Jetz 2010) take into account the extinction of species, the analyses are run under the assumption that body size of the species that survived the human invasion did not change after the colonisation. However, we showed indirect evidence that body size of Kagu has changed in the last 1800 years. This kind of human-induced change of body size has been documented in mammals (Faurby and Araújo 2017; Santini et al. 2017). Berv and 
Field (2018) showed body size reduction in birds during the Cretaceous-Paleogene mass extinction event and wondered if this also happened during the Holocene. Human colonisation in the Pacific goes back several thousand years and there could be other species assumed extinct, while in reality their fossils might be forms of present day species that changed over time. The impact of humans on morphological change in birds might therefore have been underestimated, while human impact on extinction has been overestimated. We therefore encourage researchers to verify if body size reduction also occurred in other species.

Acknowledgements This study was financed by the Polish National Science Centre (grant NCN 2011/01/M/NZ8/03344). We thank J. J. H. St Clair and anonymous reviewers for useful comments on the manuscript.

Open Access This article is distributed under the terms of the Creative Commons Attribution 4.0 International License (http://creativeco mmons.org/licenses/by/4.0/), which permits unrestricted use, distribution, and reproduction in any medium, provided you give appropriate credit to the original author(s) and the source, provide a link to the Creative Commons license, and indicate if changes were made.

\section{References}

Anderson A, Sand C, Petchey F, Worthy T (2010) Faunal extinction and human habitation in New Caledonia: initial results and implications of new research at the Pindai Caves. J Pac Archaeol 1:89-109

Balouet JC, Olson SL (1989) Fossil birds from Late Quaternary deposits in New Caledonia. Smithson Contr Zool 469:1-38

Berv JS, Field DJ (2018) Genomic signature of an avian Lilliput effect across the K-Pg Extinction. Syst Biol 67:1-13

Blackburn TM, Monroe MJ, Lawson B, Cassey P, Ewen JG (2013) Body size changes in passerine birds introduced to New Zealand from the UK. NeoBiota 17:1-18

Boyer AG, Jetz W (2010) Biogeography of body size in Pacific island birds. Ecography 33:369-379

Fain MG, Houde P (2004) Parallel radiations in the primary clades of birds. Evolution 58:2558-2573

Faurby S, Araújo MB (2017) Anthropogenic impacts weaken Bergmann's rule. Ecography 40:683-684

Field DJ, Lynner C, Brown C, Darroch SAF (2013) Skeletal correlates for body mass estimation in modern and fossil flying birds. PLoS ONE 8:e82000

Fisk DL, Latta LC IV, Knapp RA, Pfrender ME (2007) Rapid evolution in response to introduced predators. I. Rates and patterns of morphological and life-history trait divergence. BMC Evol Biol 7:22

Gargominy O, Bouchet P, Pascal M, Jaffré T, Tourneur J-C (1996) Conséquences des introductions d'espèces animales et végétales sur la biodiversité en Nouvelle-Calédonie. Rev Ecol Terre Vie 51:375-402

Grandcolas P, Murienne J, Robillard T, Desutter-Grandcolas L, Jourdan H, Guilbert E, Deharveng L (2008) New Caledonia: a very old Darwinian island? Philos Trans R Soc B 363:3309-3317

Hackett SJ, Kimball RT, Reddy S, Bowie RCK, Braun EL, Braun MJ, Chojnowski JL, Cox WA, Han KL, Harshman J, Huddleston CJ,
Marks BD, Miglia KJ, Moore WS, Sheldon FH, Steadman DW, Witt CC, Yuri T (2008) A phylogenomic study of birds reveals their evolutionary history. Science 320:1763-1768

Hunt GR (1996a) Family Rhynochetidae (Kagu). In: del Hoyo J, Elliott A, Sargatal J (eds) Handbook of the birds of the world, vol 3. Lynx Edicions, Barcelona, pp 218-224

Hunt GR (1996b) Environmental variables associated with population patterns of the Kagu Rhynochetos jubatus of New Caledonia. Ibis 138:778-785

Hunt GR, Hay R, Veltman CJ (1996) Multiple Kagu Rhynochetos jubatus deaths caused by dog attacks at a high-altitude study site on Pic Ningua, New Caledonia. Bird Conserv Int 6:295-306

Jaffré T, Bouchet P, Veillon JM (1998) Threatened plants of New Caledonia: is the system of protected areas adequate? Biodiv Conserv 7:109-135

Latham M, Quantin P, Aubert G (1978) Étude des sols de la NouvelleCalédonie. Notice explicative 78. ORSTOM, Paris

Layard EL, Layard ELC (1882) Notes on the avifauna of New Caledonia, a catalogue of the birds of the island known to E. L. \& E. L. C. Layard, with remarks by the Rev. Canon Tristram. Ibis 24:493-546

Létocart Y (2000) Suivi de la nidification des cagous (Rhynochetos jubatus) dans le Parc Provincial de la Rivière Bleue et des jeunes cagous nés dans ce parc (1988-1998). Service des Parcs et Réserves Terrestres, Direction des Ressources Naturelles, Province Sud, New Caledonia

Olson VA, Davies RG, Orme CDL, Thomas GH, Meiri S, Blackburn TM, Gaston KJ, Owens IPF, Bennett PM (2009) Global biogeography and ecology of body size in birds. Ecol Lett 12:249-259

Phillimore AB, Orme CDL, Thomas GH, Blackburn TM, Bennett PM, Gaston KJ, Owens IPF (2008) Sympatric speciation in birds is rare: insights from range data and simulations. Am Nat 171:646-657

Phillips BL, Shine R (2004) Adapting to an invasive species: toxic Cane Toads induce morphological change in Australian snakes. PNAS 101:17150-17155

Prum RO, Berv JS, Dornburg A, Field DJ, Townsend JP, Lemmon EM, Lemmon AR (2015) A comprehensive phylogeny of birds (Aves) using targeted next-generation DNA sequencing. Nature 526:569-573

Rouys S, Theuerkauf J (2003) Factors determining the distribution of introduced mammals in nature reserves of the Southern Province, New Caledonia. Wildl Res 30:187-191

Santini L, González-Suárez M, Rondinini C, Di Marco M (2017) Shifting baseline in macroecology? Unravelling the influence of human impact on mammalian body mass. Div Distr 23:640-649

Santos AMC, Field R, Ricklefs RE (2016) New directions in island biogeography. Global Ecol Biogeogr 25:751-768

Sidorovich V, Kruuk H, Macdonald DW (1999) Body size, and interactions between European and American Mink (Mustela lutreola and M. vison) in Eastern Europe. J Zool 248:521-527

Steadman DW, Martin PS (2003) The Late Quaternary extinction and future resurrection of birds on Pacific islands. Earth Sci Rev 61:133-147

Theuerkauf J, Haneda T, Sato NJ, Ueda K, Kuehn R, Gula R, Watanabe I (2015) Naturally high heavy metal concentrations in feathers of the flightless Kagu Rhynochetos jubatus. Ibis 157:177-180

Theuerkauf J, Haneda T, Okahisa Y, Sato NJ, Rouys S, Bloc H, Ueda K, Watanabe I, Kuehn R, Gula R (2017) Elevated concentrations of naturally occurring heavy metals inversely correlate with reproductive output and body mass of the Kagu Rhynochetos jubatus. Ibis 159:580-587 